ОРИГИНАЛНИ НАУЧНИ ЧЛАНЦИ

ОРИГИНАЛЬНЫЕ НАУЧНЫЕ СТАТЬИ

ORIGINAL SCIENTIFIC PAPERS

\title{
A NOTE ON THE MEIR-KEELER THEOREM IN THE CONTEXT OF $b$ - METRIC SPACES
}

\author{
Mirjana V. Pavlovića, Stojan N. Radenovićb \\ a University of Kragujevac, Faculty of Science, Department of \\ Mathematics and Informatics, Kragujevac, Republic of Serbia, \\ e-mail:mpavlovic@kg.ac.rs, \\ ORCID iD: Dhttp://orcid.org/0000-0001-6257-8666, \\ ${ }^{b}$ King Saud University, College of Science, Mathematics Department, \\ Riyadh, Saudi Arabia, \\ e-mail: radens@beotel.rs, \\ ORCID iD: (1)https://orcid.org/0000-0001-8254-6688
}

DOI: 10.5937/vojtehg67-19220; https://doi.org/10.5937/vojtehg67-19220

FIELD: Mathematics (Mathematics Subject Classification: primary $47 \mathrm{H} 10$, secondary $54 \mathrm{H} 25)$

ARTICLE TYPE: Original Scientific Paper

ARTICLE LANGUAGE: English

\section{Abstract:}

In this note we consider the famous Meir-Keeler's theorem in the context of b-metric spaces. Our result generalizes, improves, compliments, unifies and enriches several known ones in the existing literature. Also, our proof of Meir-Keeler's theorem in the context of standard metric spaces is much shorter and nicer than the ones in (Ćirić, 2003) and (Meir \& Keeler, 1969, pp.326-329).

Keywords: b-metric space, b-complete, b-Cauchy, Meir-Keeler conditions, Picard sequence.

\section{Definitions, notations and preliminaries}

Let $(X, d)$ be a standard metric space and $f: X \rightarrow X$ be a selfmapping. In the context of these spaces, the following (Meir-Keeler) conditions are well known: For each $\varepsilon>0$ there exists $\delta=\delta(\varepsilon)>0$ such that for all $x, y \in X$ holds

ACKNOWLEDGMENT: The first author is grateful for the financial support from the Ministry of Education and Science and Technological Development of the Republic of Serbia (Metode numeričke i nelinearne analize sa primenama, 174002). 
$\varepsilon \leq d(x, y)<\varepsilon+\delta$ implies $d(f x, f y)<\varepsilon$

or

$\varepsilon<d(x, y)<\varepsilon+\delta$ implies $d(f x, f y) \leq \varepsilon$

or $f$ is contractive and

$\varepsilon \leq d(x, y)<\varepsilon+\delta$ implies $d(f x, f y) \leq \varepsilon$.

One says that the mapping $f$ defined on the standard metric space $(X, d)$ is contractive if $d(f x, f y)<d(x, y)$ holds, whenever $x \neq y$.

For more details, see (Ćirić, 2003, pp.30-33, pp.56-58).

In 1969, Meir-Keeler proved the following:

Theorem 1 (Meir \& Keeler, 1969, pp.326-329, Theorem) Let $(X, d)$ be a complete metric space and let $f$ be a self-mapping on $X$ satisfying (1). Then $f$ has a unique fixed point, say $u \in X$, and for each $x \in X, \lim _{n \rightarrow \infty} f^{n} x=u$.

Inspired by the above Meir-Keeler theorem, Ćirić proved the following, slightly more general result:

Theorem 2 (Ćirić, 2003, Theorem 2.5) Let $(X, d)$ be a complete metric space and let $f$ be a self-mapping on $X$ satisfying (2). Then $f$ has a unique fixed point, say $u \in X$, and for each $x \in X, \lim _{n \rightarrow \infty} f^{n} x=u$.

The example which follows shows that Ćirićs result is a proper generalization of the famous Meir-Keeler theorem:

Example 3 Let $X=[0,1] \cup\{3 n-1\}_{n \in N} \cup\left\{3 n+\frac{1}{3 n}\right\}_{n \in N}$ be a subset of real numbers with the Euclidean metric and let $f$ be a self-mapping on $X$ defined by

$$
\begin{aligned}
& f x=0, \text { if } 0 \leq x \leq 1 \text { and } x \in\{3 n-1\}_{n \in N}, \\
& f x=1, \text { if } x \in\left\{3 n+\frac{1}{3 n}\right\}_{n \in N} .
\end{aligned}
$$


Then one can verify that $f$ satisfies (2) while it does not satisfy MeirKeeler condition (1). For all details, see (Ćirić, 2003, p.33).

Remark 1 Both previous theorems are true if the self-mapping $f: X \rightarrow X$ satisfies condition (3).

Bakhtin (Bakhtin, 1989, pp.26-37) and Czerwik (Czerwik, 1993, pp.5-11) introduced $b$-metric spaces (as a generalization of metric spaces) and proved the contraction principle in this context. In the last period, many authors have obtained fixed point results for single-valued or set-valued functions, in the context of $b$-metric spaces. Now we give the definition of a $b$-metric space:

Definition 1.1 (Bakhtin, 1989, pp.26-37), (Czerwik, 1993, pp.5-11) Let $X$ be a nonempty set and let $s \geq 1$ be a given real number. The function $d: X \times X \rightarrow[0, \infty)$ is said to be a $b$-metric if, and only if, for all $x, y, z \in X$ the following conditions hold:

b1) $d(x, y)=0$ if, and only if, $x=y$;

b2) $d(x, y)=d(y, x)$;

b3) $d(x, z) \leq s[d(x, y)+d(y, z)]$.

A triplet $(X, d, s \geq 1)$ is called a $b$-metric space with the coefficient $s$.

It should be noted that the class of $b$-metric spaces is effectively larger than that of standard metric spaces, since a b-metric is a metric when $s=1$. The following example shows that, in general, a $b$-metric does not necessarily need to be a metric (Chandok et al, 2017, pp.331345), (Došenović et al, 2017, pp.851-865), (Dubey et al, 2014), (Dung \& Hang, 2018, pp.298-304), (Faraji \& Nourouzi, 2017, pp.77-86), (Jovanović et al, 2010), (Jovanović, 2016), (Kir \& Kiziltunc, 2016, pp.1316), (Kirk \& Shahzad, 2014).

Example 4 Let $(X, \rho)$ be a standard metric space, and $d(x, y)=(\rho(x, y))^{p}, p>1$ is a real number. Then $d$ is a $b$-metric with $s=2^{p-1}$, but $d$ is not a standard metric on $X$.

Otherwise, for more concepts such as $b$-convergence, $b$ completeness, $b$-Cauchy and $b$-closed set in $b$-metric spaces, we refer 
the reader to (Došenović et al, 2017, pp.851-865), (Dubey et al, 2014), (Dung \& Hang, 2018, pp.298-304), (Faraji \& Nourouzi, 2017, pp.77-86), (Jovanović et al, 2010), (Jovanović, 2016), (Kir \& Kiziltunc, 2016, pp.1316), (Kirk \& Shahzad, 2014), (Koleva \& Zlatanov, 2016, pp.31-34), (Chifu \& Petruşel, 2017, pp.2499-2507), (Kumar et al, 2014, pp.19-22), (Miculescu \& Mihail, 2017, pp.1-11), (Paunović et al, 2017, pp.41624174), (Singh et al, 2008, pp.401-416), (Sintunavarat, 2016, pp.397-416), (Suzuki, 2017), (Zare \& Arab, 2016, pp.56-67).

The following two lemmas are very significant in the theory of a fixed point in the context of $b$-metric spaces.

Lemma 1.2 (Jovanović et al, 2010, p.15, Lemma 3.1) Let $\left\{a_{n}\right\}_{n \in N \cup\{0\}}$ be a sequence in a $b$-metric space $(X, d, s \geq 1)$ such that

$$
d\left(a_{n}, a_{n+1}\right) \leq k d\left(a_{n-1}, a_{n}\right)
$$

for some $k \in\left[0, \frac{1}{s}\right)$, and each $n=1,2, \ldots$ Then $\left\{a_{n}\right\}$ is a $b$-Cauchy sequence in a $b$-metric space $(X, d, s \geq 1)$.

Lemma 1.3 (Miculescu \& Mihail, 2017, pp.1-11, Lemma 2.2) Let $\left\{a_{n}\right\}_{n \in N \cup\{0\}}$ be a sequence in a $b$-metric space $(X, d, s \geq 1)$ such that

$$
d\left(a_{n}, a_{n+1}\right) \leq k d\left(a_{n-1}, a_{n}\right)
$$

for some $k \in[0,1)$, and each $n=1,2, \ldots$ Then $\left\{a_{n}\right\}$ is a $b$-Cauchy sequence in a $b$-metric space $(X, d, s \geq 1)$.

Remark 2 In (Došenović et al, 2017, pp.851-865), it is proven that the previous lemmas are equivalent.

Since in general a $b$-metric is not necessarily continuous, many papers related with $b$-metric spaces used the following lemmas to prove the main results.

Lemma 1.4 (Aghajani et al, 2014, pp.941-960, Lemma 2.1) Let $(X, d, s \geq 1)$ be a $b$-metric space. Suppose that $\left\{a_{n}\right\}$ and $\left\{b_{n}\right\}$ are $b$ convergent to $a$ and $b$, respectively. Then

$$
\frac{1}{s^{2}} d(a, b) \leq \lim \inf _{n \rightarrow \infty} d\left(a_{n}, b_{n}\right) \leq \lim \sup _{n \rightarrow \infty} d\left(a_{n}, b_{n}\right) \leq s^{2} d(a, b) .
$$


In particular, if $a=b$, then we have $\lim _{n \rightarrow \infty} d\left(a_{n}, b_{n}\right)=0$. Moreover, for each $c \in X$, we have

$$
\frac{1}{s} d(a, c) \leq \lim \inf _{n \rightarrow \infty} d\left(a_{n}, c\right) \leq \limsup \operatorname{sum}_{n \rightarrow \infty}\left(a_{n}, c\right) \leq s d(a, c) .
$$

Lemma 1.5 (Paunović et al, 2017, pp.4162-4174, Lemma 2.3) Let $(X, d, s \geq 1)$ be a $b$-metric space and $\left\{a_{n}\right\}$ a sequence in $X$ such that

$$
\lim _{n \rightarrow \infty} d\left(a_{n}, a_{n+1}\right)=0 \text {. }
$$

If $\left\{a_{n}\right\}$ is not $b$-Cauchy, then there exist $\varepsilon>0$ and two sequences $\{m(k)\}$ and $\{n(k)\}$ of positive integers such that the following items hold:

$$
\begin{aligned}
& \varepsilon \leq \lim \inf _{k \rightarrow \infty} d\left(a_{m(k)}, a_{n(k)}\right) \leq \lim \sup _{k \rightarrow \infty} d\left(a_{m(k)}, a_{n(k)}\right) \leq \varepsilon S, \\
& \frac{\varepsilon}{S} \leq \lim \inf _{k \rightarrow \infty} d\left(a_{m(k)}, a_{n(k)+1}\right) \leq \lim \sup _{k \rightarrow \infty} d\left(a_{m(k)}, a_{n(k)+1}\right) \leq \varepsilon s^{2}, \\
& \frac{\varepsilon}{S} \leq \lim \inf _{k \rightarrow \infty} d\left(a_{m(k)+1}, a_{n(k)}\right) \leq \limsup d\left(a_{m(k)+1}, a_{n(k)}\right) \leq \varepsilon s^{2} \text {, } \\
& \frac{\varepsilon}{s^{2}} \leq \lim \inf _{k \rightarrow \infty} d\left(a_{m(k)+1}, a_{n(k)+1}\right) \leq \lim \sup _{k \rightarrow \infty} d\left(a_{m(k)+1}, a_{n(k)+1}\right) \leq \varepsilon s^{3} \text {. }
\end{aligned}
$$

In particular, if $s=1$ and $\left\{a_{n}\right\}$ is not a $b$-Cauchy sequence, then there exists $\varepsilon>0$ as well as two sequences $\{m(k)\}$ and $\{n(k)\}$ of positive integers such that the sequences

$$
d\left(a_{m(k)}, a_{n(k)}\right), d\left(a_{m(k)}, a_{n(k)+1}\right), d\left(a_{m(k)+1}, a_{n(k)}\right) \text { and } d\left(a_{m(k)+1}, a_{n(k)+1}\right)
$$

tend to $\varepsilon^{+}$as $k \rightarrow \infty$.

\section{Main result}

Now, according to the last Lemma (the condition $s=1$ ), we formulate and prove the following result:

Theorem 5 Let $(X, d)$ be a complete metric space and let $f$ be a contractive self-mapping on $X$ satisfying the next condition:

Given $\varepsilon>0$, there exists $\delta>0$ such that for all $x, y \in X$

$$
\varepsilon \leq d(x, y)<\varepsilon+\delta \text { implies } d(f x, f y) \leq \varepsilon .
$$


Then $f$ has a unique fixed point, say $u \in X$, and for each $x \in X, \lim _{n \rightarrow \infty} f^{n} x=u$.

Proof. Let $x_{0}$ in $X$ be arbitrary. Consider the sequence of iterates $\left\{f^{n} x_{0}\right\}_{n=0}^{+\infty}$. If $d\left(f^{n} x_{0}, f^{n+1} x_{0}\right)=d\left(f^{n} x_{0}, f f^{n} x_{0}\right)=0$ for some $n \in N$, then $a_{n}=f^{n} x_{0}$ is a fixed point of $f$. Assume now that $d\left(f^{n} x_{0}, f^{n+1} x_{0}\right)>0$ for all $n \in N$. Since $f$ is contractive, the sequence $\left\{d\left(f^{n} x_{0}, f^{n+1} x_{0}\right)\right\}_{n=0}^{+\infty}$ is strictly decreasing. Therefore, there exists the limit of this sequence, say $\varepsilon$, and $d\left(f^{n} x_{0}, f^{n+1} x_{0}\right)>\varepsilon$ for all $n \in N$. Assume that $\varepsilon>0$. In this case, by hypothesis, there exists a suitable $\delta=\delta(\varepsilon)>0$ such that (5) holds. From the definition of $\varepsilon$, it follows that there is $n \in N$ such that

$$
\varepsilon \leq d\left(f^{n} x_{0}, f^{n+1} x_{0}\right)<\varepsilon+\delta .
$$

According to (5), we get that

$d\left(f f^{n} x_{0}, f f^{n+1} x_{0}\right)=d\left(f^{n+1} x_{0}, f^{n+2} x_{0}\right) \leq \varepsilon$,

a contradiction. Therefore $\lim _{n \rightarrow \infty} d\left(f^{n} x_{0}, f^{n+1} x_{0}\right)=0$.

Now we show that $\left\{f^{n} x_{0}\right\}_{n=0}^{++\infty}$ is a Cauchy sequence. If this is not the case, by applying Lemma 1.5 to the sequence $\left\{f^{n} x_{0}\right\}_{n=0}^{+\infty}$, we get that there exist $\varepsilon>0$ and two sequences of positive integers $\{m(k)\}$ and $\{n(k)\}$ such that $n(k)>m(k)>k$, and sequences (4) tend to $\varepsilon^{+}$as $k \rightarrow \infty$. Using the condition (5) with $x=a_{m(k)}, y=a_{n(k)}$ and the $\delta=\delta(\varepsilon)>0$, ones obtains that there exists a positive integer $l$ such that for each $k \geq l$, we have $\varepsilon \leq d\left(a_{m(k)}, a_{n(k)}\right)=d\left(f a_{m(k)-1}, f a_{n(k)-1}\right)<\varepsilon+\delta$ implies $d\left(f a_{m(k)}, f a_{n(k)}\right) \leq \varepsilon$.

This contradicts the fact that

$d\left(f a_{m(k)}, f a_{n(k)}\right)=d\left(a_{m(k)+1}, a_{n(k)+1}\right) \rightarrow \varepsilon^{+}$as $k \rightarrow \infty$.

Hence, $\left\{f^{n} x_{0}\right\}_{n=0}^{++\infty}$ is a Cauchy sequence.

The proof is further as in (Ćirić, 2003) and (Meir \& Keeler, 1969, pp.326-329). 
To our knowledge, it is not known whether Meir-Keeler's and Ćiric's theorems hold in the context of a b-metric space. Also, there is no known example that confirms that conditions (1) or (2) or (3) holds in the context of $b$-metric spaces but that $f$ does not have a fixed point.

However, with a stronger condition than (1), we have the positive result. Hence, our main result is the following:

Theorem 6 Let $(X, d, s>1)$ be a $b$-complete $b$-metric space and let $f$ self-mapping on $X$ satisfy the following condition:

Given $\varepsilon>0$, there exists $\delta>0$ such that

$\varepsilon \leq d(x, y)<\varepsilon+\delta$ implies $s^{a} d(f x, f y)<\varepsilon$,

where $a>0$ is given.

Then $f$ has a unique fixed point, say $u \in X$, and for each $x \in X, \lim _{n \rightarrow \infty} f^{n} x=u$.

Proof. It is clear that for all $x, y \in X$ we obtain

$d(f x, f y) \leq k d(x, y)$,

where $k=\frac{1}{s^{a}} \in[0,1)$.

Let $a_{0} \in X$ be an arbitrary point. Define the sequence $\left\{a_{n}\right\}$ by $a_{n+1}=f a_{n}$ for all $n \geq 0$. If $a_{n}=a_{n+1}$ for some $n$, then $a_{n}$ is a fixed point (unique) of $f$ and the results follows.

So, suppose that $a_{n} \neq a_{n+1}$ for all $n \geq 0$. From the condition (8), we obtain

$$
d\left(a_{n}, a_{n+1}\right) \leq k d\left(a_{n-1}, a_{n}\right) .
$$

Further, according to (Miculescu \& Mihail, 2017, pp.1-11, Lemma 2.2.) we obtain that $\left\{a_{n}\right\}$ is a $b$-Cauchy sequence in a $b$-metric space $(X, d)$. By the $b$-completeness of $(X, d)$, there exists $u \in X$ such that

$$
\lim _{n \rightarrow \infty} a_{n}=u \text {. }
$$

Finaly, (8) and (10) imply that $f u=u$, i.e. $u$ is a unique fixed point of $f$ in $X$. 
For the following facts and definitions, we refer to (Aghajani et al, 2014, pp.941-960), (Jovanović, 2016) and (Kirk \& Shahzad, 2014) and the references therein.

Definition 2.1 Let $f$ and $g$ be self-mappings of a nonempty set $X$ such that $f(X) \subset g(X)$. Let $x_{0} \in X$ be an arbitrary point. Then $f x_{0} \in g(X)$, so we can assume that $f x_{0}=g x_{1}=y_{0}$ (say) for some $x_{1} \in X$. Again, $f x_{1} \in g(X)$, so we can choose $x_{2} \in X$ such that $f x_{1}=g x_{2}=y_{1}$ (say). Similarly, we can construct two sequences $\left\{x_{n}\right\}$ and $\left\{y_{n}\right\}$ such that $y_{n}=f x_{n}=g x_{n+1}$ for all $n \geq 0$. Here the sequence $\left\{y_{n}\right\}$ is called a corresponding Jungck sequence for the point $x_{0} \in X$.

Definition 2.2 Let $f$ and $g$ be the self-mappings of a nonempty set $X$. If $z=f x=g x$ for some $x$ in $X$, then $x$ is called a coincidence point of $f$ and $g$, and $z$ is called a point of coincidence of $f$ and $g$. The mappings $f$ and $g$ are called weakly compatible if they commute at their coincidence points.

Lemma 2.3 Let $f$ and $g$ be the weakly compatible self-maps of a nonempty set $X$. If $f$ and $g$ have a unique point of coincidence $z=f x=g x$, then $z$ is the unique common fixed point of $f$ and $g$.

Now, we announce the following result which generalizes Theorem 5 in several directions:

Theorem 7 Let $(X, d, s>1)$ be a $b$-complete $b$-metric space and let $f, g: X \rightarrow X$ be two self-maps such that $f(X) \subset g(X)$, one of these two subsets of $X$ being b-complete. Suppose the following conditions hold:

for each $\varepsilon>0$ there exists $\delta>0$ such that

$\varepsilon \leq d(g x, g y)<\varepsilon+\delta$ implies $s^{a} d(f x, f y)<\varepsilon$

and $f x=f y$ whenever $g x=g y$,

where $a>0$ is given. 
Then $f$ and $g$ have a unique point of coincidence, say $z \in X$. Moreover, for each $x_{0} \in X$, the corresponding Jungck sequence $\left\{y_{n}\right\}$ can be chosen such that $\lim _{n \rightarrow \infty} y_{n}=z$. In addition, if $f$ and $g$ are weakly compatible, then they have a unique common fixed point.

Finally, we have an open question:

\section{Prove or disprove the following:}

- Let $(X, d, s>1)$ be a b-complete b-metric space and $f, g: X \rightarrow X$ be two given mappings such that $f(X) \subset g(X)$, one of these two subsets of $X$ being $b$-complete. Assume that the following conditions hold:

for each $\varepsilon>0$, there exists $\delta=\delta(\varepsilon)>0$ such that $\varepsilon \leq d(g x, g y)<\varepsilon+\delta$ implies $d(f x, f y)<\varepsilon$ and $f x=f y$, whenever $g x=g y$.

Then $f$ and $g$ have a unique point of coincidence, say $z \in X$. Moreover, if $f$ and $g$ are weakly compatible, then they have a unique common fixed point.

\section{References}

Aghajani, A., Abbas, M., \& Roshan, J. 2014. Common fixed point of generalized weak contractive mappings in partially ordered b-metric spaces. Mathematica Slovaca, 64(4), pp.941-960. Available at: https://doi.org/10.2478/s12175-014-0250-6.

Bakhtin, I.A. 1989. The contraction principle in quasimetric spaces. Funct. Anal, 30, pp.26-37.

Chandok, S., Jovanovic, M., \& Radenovic, S. 2017. Ordered b-metric spaces and Geraghty type contractive mappings. Vojnotehnički glasnik/Military Technical Courier, 65(2), pp.331-345. Available at: https://doi.org/10.5937/vojtehg65-13266.

Chifu, C., \& Petruşel, G. 2017. Fixed point results for multivalued hardyrogers contractions in b-metric spaces. Filomat, 31(8), pp.2499-2507. Available at: https://doi.org/10.2298/fil1708499c.

Czerwik, S. 1993. Contraction mappings in b-metric spaces. Acta Math. Inform., Univ. Ostrav, 1(1), pp.5-11. Available at: https://dml.cz/handle/10338.dmlcz/120469. Accessed: 10.10.2018.

Ćirić, Lj. 2003. Fixed Point Theory: Contraction Mapping Principle.Belgrade: Faculty of Mechanical Engineering. 
Došenović, T., Pavlović, M., \& Radenović, S. 2017. Contractive conditions in b-metric spaces. Vojnotehnički glasnik/Military Technical Courier, 65(4), pp.851-865. Available at: https://doi.org/10.5937/vojtehg65-14817.

Dubey, A.K., Shukla, R., \& Dubey, R.P. 2014. Some fixed point results in bmetric spaces. Asian J. Math. Appl., article ID ama0147.

Dung, N.V., \& Hang, V.T.L. 2018. On The Completion Of b-Metric Spaces. Bulletin of the Australian Mathematical Society, 98(2), pp.298-304. Available at: https://doi.org/10.1017/s0004972718000394.

Faraji, H., \& Nourouzi, K. 2017. A generalization of Kannan and Chatterjea fixed point theorem on complete b-metric spaces. Sahand Communications in Mathematical Analysis (SCMA), 6(1), pp.77-86. Available at: https://doi.org/10.22130/SCMA.2017.23831.

Jovanović, M., Kadelburg, Z., \& Radenović, S. 2010. Common Fixed Point Results in Metric-Type Spaces. Fixed Point Theory and Applications, 2010, Article ID:978121. Available at: https://doi.org/10.1155/2010/978121.

Jovanović, M. 2016. Contribution to the theory of abstract metric spaces. Belgrade. Available at: http://nardus.mpn.gov.rs/handle/123456789/7975. Accessed: 10.10.2018.

Kir, M., \& Kiziltunc, H. 2016. On Some Well Known Fixed Point Theorems in b-Metric Spaces. Turkish Journal of Analysis and Number Theory, 1(1), pp.1316. Available at: https://doi.org/10.12691/tjant-1-1-4.

Kirk, W., \& Shahzad, N. 2014. Fixed Point Theory in Distance Spaces. Switzerland: Springer International Publishing.

Koleva, R., \& Zlatanov, B. 2016. On fixed points for Chatterjea's maps in bmetric spaces. Turkish Journal of Analysis and Number Theory, 4(2), pp.31-34. Available at: http://www.sciepub.com/TJANT/abstract/6009. Accessed: 10.10.2018.

Kumar, M.P., Sachdeva, S., \& K. Banerjee, S. 2014. Some Fixed Point Theorems in b-metric Space. Turkish Journal of Analysis and Number Theory, 2(1), pp.19-22. Available at: https://doi.org/10.12691/tjant-2-1-5.

Meir, A., \& Keeler, E. 1969. A theorem on contraction mappings. Journal of Mathematical Analysis and Applications, 28(2), pp.326-329. Available at: https://doi.org/10.1016/0022-247x(69)90031-6.

Miculescu, R., \& Mihail, A. 2017. New fixed point theorems for set-valued contractions in b-metric spaces. Journal of Fixed Point Theory and Applications, 19(3), pp.2153-2163. Available at: https://doi.org/10.1007/s11784016-0400-2.

Paunović, Lj., Kaushik, P., \& Kumar, S. 2017. Some applications with new admissibility contractions in b-metric spaces. The Journal of Nonlinear Sciences and Applications, 10(08), pp.4162-4174. Available at: https://doi.org/10.22436/jnsa.010.08.12.

Singh, S.L., Czerwik, S., Krol, K., \& Singh, A. 2008. Coincidences and fixed points of hybrid contractions. Tamsui Oxf. J. Math. Sci., 24, pp.401-416. 
Sintunavarat, W. 2016. Nonlinear integral equations with new admissibility types in b-metric spaces. J. Fixed Point Theory Appl., 18(2), pp.397-416. Available at: https://doi.org/10.1007/s11784-015-0276-6.

Suzuki, T. 2017. Basic inequality on a b-metric space and its applications. Journal of Inequalities and Applications, 2017:256. Available at: https://doi.org/10.1186/s13660-017-1528-3.

Zare, K., \& Arab, R. 2016. Common fixed point results for infinite families in partially ordered b-metric spaces and applications. Electronic Journal of Mathematical Analysis and Applications, 4(2), pp.56-67. Available at: http://mathfrac.org/Journals/EJMAA/Vol4(2)_July_2016/Vol4(2)_Papers/06_EJMAA_Vol4(2)_J uly_2016_pp_56-67.pdf. Accessed: 15.10.2018.

ЗАМЕТКА О ТЕОРЕМЕ МЕИРА-КИЛЕРА В КОНТЕКСТЕ b-МЕТРИЧЕСКИХ ПРОСТРАНСТВ

Мирьяна В. Павлович ${ }^{a}$, Стоян Н. Раденович

а Университет в г. Крагуевац, Естественно-математический фракультет, г. Крагуевац, Республика Сербия,

${ }^{\sigma}$ Университет короля Сауда, Естественно-математический фракультет, Департамент математики, Рияд, Саудовская Аравия

ОБЛАСТЬ: математика (математическая тематическая классификация: первичная $47 \mathrm{H} 10$, вторичная $54 \mathrm{H} 25$ )

ВИД СТАТЬИ: оригинальная научная статья

ЯЗЫК СТАТЬИ: английский

Резюме:

В данной работе рассматривается знаменитая теорема МеираКилера в контексте b-метрических пространств. Наш результат обобщает, улучшает, дополняет и объединяет ранее полученные результаты, которые были опубликованы в научной литературе. Hаше доказательство намного короче $u$ лучше, чем доказательства, представленные в иных работах (Ћирић, 2003) и (Meir \& Keeler, 1969, pp.326-329).

Ключевые слова: b-метрическое пространство, b-полная система фрункций, b-Коши, условия Меира-Килера, последовательности Пикарда.

\section{БЕЛЕШКА О MEIR-KEELER-OBOJ TEOPEMИ У КОНTЕКСТУ} b-МЕТРИЧКИХ ПРОСТОРА

Мирјана В. Павловић ${ }^{\text {a }}$ Стојан Н. Раденовић ${ }^{6}$

а Универзитет у Крагујевцу, Природно-математички факултет, Крагујевац, Република Србија,

${ }^{\sigma}$ Универзитет краља Сауда, Природно-математички фракултет, Департман математике, Ријад, Саудијска Арабија 
ОБЛАСТ: математика (математичка тематска класификација: примарна 47H10, секундарна 54H25)

ВРСТА ЧЛАНКА: оригинални научни чланак ЈЕЗИК ЧЛАНКА: енглески

\section{Сажетак:}

У овом раду разматрана је позната Meir-Keeler-ова mеорема у контексту b-метричких простора. Наш резултат генерализује, побољшава, даје допринос, уједињује и обогаћује познате резултате у научној литератури. Такође, наш доказ Meir-Keelerове теореме у контексту стандардних метричких простора је много краћи и прикладнији него у радовима Ћирића, (2003) и Meir \& Keeler-a (1969, pp.326-329).

Кључне речи: b-метрички простор, b-комплетан, b-Саuchy-jeв, Meir-Keeler-ови услови, Picard-ов низ.

Paper received on / Дата получения работы / Датум пријема чланка: 18.10.2018. Manuscript corrections submitted on / Дата получения исправленной версии работы / Датум достављања исправки рукописа: 26.11.2018.

Paper accepted for publishing on / Дата окончательного согласования работы / Датум коначног прихватања чланка за објављивање: 28.11.2018.

() 2019 The Authors. Published by Vojnotehnički glasnik / Military Technical Courier (www.vtg.mod.gov.rs, втг.мо.упр.срб). This article is an open access article distributed under the terms and conditions of the Creative Commons Attribution license (http://creativecommons.org/licenses/by/3.0/rs/).

() 2019 Авторы. Опубликовано в «Военно-технический вестник / Vojnotehnički glasnik / Military Technical Courier» (www.vtg.mod.gov.rs, втг.мо.упр.срб). Данная статья в открытом доступе и распространяется в соответствии с лицензией «Creative Commons» (http://creativecommons.org/licenses/by/3.0/rs/).

( 2019 Аутори. Објавио Војнотехнички гласник / Vojnotehnički glasnik / Technical Courier (www.vtg.mod.gov.rs, втг.мо.упр.срб). Ово је чланак отвореног приступа и дистрибуира се у складу са Creative Commons licencom (http://creativecommons.org/licenses/by/3.0/rs/)

\section{(c) (i)}

